\title{
The development of the intratesticular excurrent duct system of donkey (Equus asinus) from birth to maturity
}

\author{
Abd-Elhafeez HH*, Moustafa MNK, Zayed AE and Sayed R \\ Department of Anatomy and Histology, Assuit University, Egypt
}

\begin{abstract}
The testis of the donkey was completely descended into the scrotum around birth. It was covered by a thick tunica albuginea consisting of outer and inner fibrous layers in addition to middle vascular one. Discrete bundles of smooth muscle cells were demonstrated in the outer fibrous layer of the tunica albuginea. These cells give the tunica albuginea a contractile function, which may aid in sperm transport. The present study emphasized an irregular arrangement of the testicular lobules of the donkey during various stages of the postnatal life. Such arrangement does not allow some lobules to have direct contact with the mediastinum testis. The latter was located paraxially, toward the epididymal border and extended about two-thirds of the testicular length; it is thick at the head extremity and gradually faded out caudal wards. The connection between the seminiferous cords and the initial part of the straight tubules exhibited a sharp cut contact in neonates, but it demonstrated exfoliated supporting and germ cells, as well as crowded population of peritubular cells in suckling animals. In premature ones, the connection between the seminiferous tubules and straight testicular tubules was characterized by a peculiar structure appearance that attained more modification and development. This connection included two regions; terminal segment of the seminiferous tubule and a dilated initial part of the straight tubule. In mature stage, the terminal segment was composed of three regions with different cellular composition. The duct system of the donkey testis included the intralobular, interlobular, mediastinal and tunical segments in addition to the efferent ductules. From the seminiferous tubules to the efferent ductules, the lining epithelium was essentially the same in cellular composition; however these passages differed in size and configuration from region to another.
\end{abstract}

\section{Introduction}

The adult mammalian testis is the important organ within the male reproductive system and has two major physiological functions: the production of spermatozoa via spermatogenesis and testosterone (TE) via steroidogenesis [1].

The parenchyma of the testis is surrounded by a capsule consisting of two layers; the visceral layer of the tunica vaginalis and tunica albuginea. The tunica albuginea consists predominantly of collagen fibers and few elastic fibers. Smooth muscle cells are occasionally present in the tunica albuginea of stallion [2]. A vascular layer is present in the tunica albuginea of most species. It is superficial in dogs and rams, but deep in stallions and boars [3]. The tunica albuginea is continuous with the septulae testis, which converges towards the mediastinum testis. The septa are rather complete in the dog and boar whereas they are inconspicuous in other domestic animals. The septulae testis divides the testicular parenchyma into a varying number of testicular lobules. Each contains one to four convoluted seminiferous tubules. They are continuous with the mediastinum testis, a connective tissue area containing the channels of the rete testis and large blood and lymph vessels. The mediastinum testis of the stallion, cat, and many rodents is relatively small and located in a marginal position, whereas, in ruminants, pigs and dogs, it occupies a central position along the longitudinal axis of the gonad [4].

The Intratesticular excurrent duct system of the adult testis consists of a terminal segment of the convoluted seminiferous tubules, straight tubules, and rete testis. The terminal segment is a short transitional zone connects between seminiferous tubules and tubuli recti [5].

The nomenclature and origin of the excurrent duct system of the testis are a matter of controversy. The spatial topography of the excurrent duct system of the mammalian testis has been described by several authors in horse, goat, bull, cat [6-10].

Amman et al. described the connection between the seminiferous tubules and the efferent ducts in the stallion [6]. They concluded that many straight tubules led directly to the dorsocrainal pole of the testis but that others led to that portion of the rete testis which was located more caudally around the central vein. The rete testis, extended about two-thirds the length of the testis and penetrated the tunica albuginea to form an extratesticular rete testis before connecting with the efferent ducts. Union of the straight seminiferous tubules and efferent ducts were typically extratesticular rather than within the testis, although one connection which might be considered as lying within the tunica albuginea was seen. The equine testis is an interesting organ due to the presence of smooth musculature in tunica albuginea and septula testis. Furthermore, the similarity with the inner organization of human testis (position of mediastinum and rete testis) may allow comparisons to be made between these two species.

Due to the scanty of information about the donkey mediastinum and rete testis, the present investigation was undertaken to try to get a correct picture of the donkey mediastinum and rete testis during the postnatal period from birth until puberty.

Correspondence to: Hanan H. abdelhafeez,Assistant professor,Department of anatomy,Embryology and histology.Faculty of veterinary medicine, Assuit, Egypt, E-mail: hhmmzz91@gmail.com

Key words: development, donkey testis, interstitial cells, morphology, morphometry

Received: April 08, 2017; Accepted: May 02, 2017; Published: May 06, 2017 


\section{Materials and methods}

The present investigation was carried out on 20 testes from 20 healthy donkeys representing different stages of postnatal life including newly born, early and late suckling, premature and mature (Table 1). The left testis and the adjoining spermatic cord were obtained by castration in the Department of Anatomy and Histology, Faculty of Veterinary Medicine, Assiut University. They were slowly perfused through the testicular artery using a small amount of neutral buffered formalin to avoid expansion of the testicular vessels.

\section{A) Paraffin embedding:}

Small blocks $(1 \times 1 \times 1 / 2 \mathrm{~cm})$ were taken from different regions of the testis according to the schedule presented in Figures $1 \mathrm{~A}$ and $1 \mathrm{~B}$. The samples were immersed in a special fixative [11] for 24 hours and Table 2 is explaining the components of fixative.

After fixation, the specimens were dehydrated in ascending grades of ethanol, cleared in methyl benzoate and embedded in paraffin. 5-7 $\mu \mathrm{m}$ thick sections were cut and stained with Haematoxylin and Eosin, Crossman's trichrome stains and PAS technique [12-14].

\section{B) Epon-Araldite embedding:}

Small pieces 2.0-3.0 mm long were fixed in Karnovsky fixative; Table 2 is explaining the components of fixative Karnovat $4^{\circ} \mathrm{C}$ overnight [15]. They were washed 4 times for 15 minutes in $0.1 \mathrm{M}$ sodium phosphate buffer ( $\mathrm{pH} 7.2$ ) then were post-fixed in $1 \%$ osmic acid in $0.1 \mathrm{M} \mathrm{Na}$ phosphate buffer at $4^{\circ} \mathrm{C}$ for 2 hours. The samples were again washed 3 times for 20 minutes in $0.1 \mathrm{M}$ phosphate buffer ( $\mathrm{pH}$ 7.2). Dehydration was performed through graded ethanol to propylene oxide. Samples were dehydrated in ascending graded series of ethanol (50\% (for 30 minutes), $70 \%$ (overnight), $90 \%$ (for 30 minutes), and 100\% I (for 30 minutes) and $100 \%$ II (60 minutes). The dehydrated samples were

Table 1. Animals used in this study.

\begin{tabular}{|l|c|}
\hline Age of animals & No. of animals \\
\hline Neonatal animals (5 days) & 3 \\
\hline Early suckling animals (2 months) & 4 \\
\hline Late suckling animals (6 and 9 months) & 4 \\
\hline Premature animals (1.5 years) & 4 \\
\hline Mature animals (2-3 years) & 5 \\
\hline
\end{tabular}

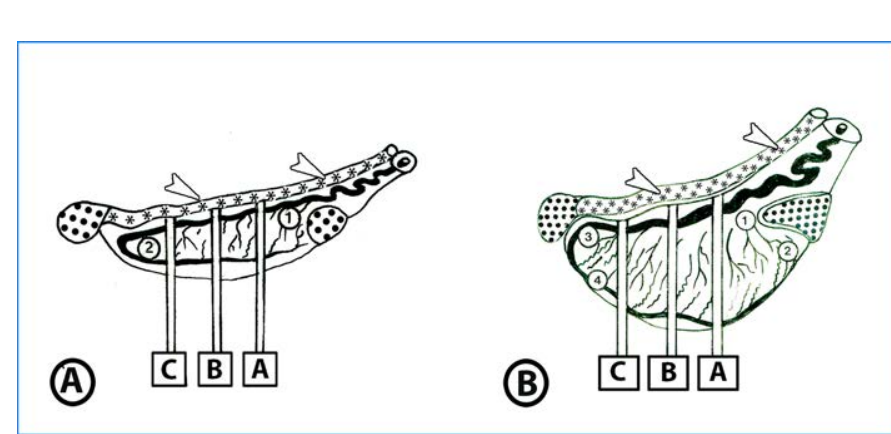

Figure 1A. Diagrammatic representation of tissue sampling from left testis in neonatal and suckling animals. Five tissue blocks are collected from different regions of testis; head extremity (1), tail extremity (2), and three complete transverse sections (A, B, C) mid-way between the head and tail extremities.

Figure 1B. Diagrammatic representation of tissue sampling from left testis of premature and mature animals. Nineteen tissue blocks are collected from different areas of the head extremity $(1,2)$, tail extremity $(3,4)$ and three transverse sections (A, B, C). Slice B is taken from the testicular equator; sections $\mathrm{A}$ and $\mathrm{C}$ are equidistant from the equator and cranial or caudal pole, respectively. From each of the three slices, five tissue blocks are obtained from the center, medial, lateral, epididymal and free sides.

• = Epididymis, *, arrow head= Ductus deference
Table 2. Components of the fixative.

\begin{tabular}{|c|c|c|}
\hline Fixative & Components & Amount \\
\hline \multirow[t]{6}{*}{ Wrobel-Moustafa-Fixative } & Paraformaldehyde, $25 \%$ freshly prepared & $40 \mathrm{ml}$ \\
\hline & Phosphate buffer (0.2 M, pH 7.4) & $125 \mathrm{ml}$ \\
\hline & Saturated picric acid & $37.5 \mathrm{ml}$ \\
\hline & Calcium chloride & $0.5 \mathrm{mg}$ \\
\hline & Glutaraldehyde $25 \%$ & $1.25 \mathrm{ml}$ \\
\hline & Add distilled water up to & $250 \mathrm{ml}$ \\
\hline \multirow[t]{4}{*}{ Karnovsky Fixative } & Paraformaldehyde, $25 \%$ freshly prepared & $10 \mathrm{ml}$ \\
\hline & Glutaraldehyde $50 \%$ & $10 \mathrm{ml}$ \\
\hline & Na-Phosphate buffer (0.1 M, pH 7.4) & $50 \mathrm{ml}$ \\
\hline & Distilled water & $30 \mathrm{ml}$ \\
\hline \multirow{9}{*}{$\begin{array}{l}\text { Na-Phosphate buffer } \\
(0.1 \mathrm{M}, \mathrm{pH} 7.4)\end{array}$} & \multicolumn{2}{|l|}{ Solution A } \\
\hline & $\mathrm{Na}_{2} \mathrm{HPO}_{4} 2 \mathrm{H}_{2} \mathrm{O}$ & $17.02 \mathrm{gm}$ \\
\hline & distilled water & $600 \mathrm{ml}$ \\
\hline & \multicolumn{2}{|l|}{ Solution B } \\
\hline & $\mathrm{NaH}_{2} \mathrm{PO}_{4} \mathrm{H}_{2} \mathrm{O}$ & $6 \mathrm{gm}$ \\
\hline & distilled water & $250 \mathrm{ml}$ \\
\hline & \multicolumn{2}{|l|}{ Using solution } \\
\hline & Solution A & $580 \mathrm{ml}$ \\
\hline & Solution B & $219 \mathrm{ml}$ \\
\hline
\end{tabular}

embedded in resin (Epon-araldite) as the following; Propylene oxide (Merck, Darmstadt, Germany) for 30 minutes, Epon: Propylene oxide about (1:1) (for $30 \mathrm{~min}$ ) then in Epon (for 3 hours). Epon was prepared (5 ml Epon812 (Polysciences, Oppenheim, Germany) $+5 \mathrm{ml}$ Araldite $+12 \mathrm{ml}$ DDSA), Epon was mixed thoroughly by shaker then put in Incubation at $60^{\circ} \mathrm{C}$ for 15 minutes. Polymerization of samples was performed by using Epon and accelerator (DMP30) (1.5\%). The blocks were incubated for 3 days as the following; $60^{\circ} \mathrm{C}$ at first day and at $70^{\circ} \mathrm{C}$ in the second day and $75^{\circ} \mathrm{C}$ at third day. Semithin sections $(1 \mu \mathrm{m})$ were cut using an ultramicrotome Ultracut E (Reichert-Leica, Germany) and stained with toluidine blue (Sodium tetraborate (borax) 1 gram, toluidine blue 1 gram, and Distilled water $100 \mathrm{ml}$ ) [16]. The sections covered the different regions of testis including mediastinum and rete testis. Stained sections were examined using DMLS light microscope (Leica, Germany) outfitted with MC120 HD camera (Leica, Germany).

\section{Results}

\section{Neonatal animals}

The testis was completely descended into the scrotum around birth. At this stage of postnatal life, the testis was surrounded by a thick tunica albuginea covered by a single layer of mesothelial cells representing the visceral layer of tunica vaginalis. The tunica albuginea was composed of three layers; outer and inner fibrous in addition to a middle vascular layer. Each fibrous layer was mostly composed of collagen and few elastic fibers, while the vascular one was represented by variably sized arterial, venous and lymphatic vessels. Several connective tissue septa were seen originating from the tunica albuginea. They appeared thick at their origin and around the large testicular vessels, but became thin in their course toward the mediastinum. Such septa appeared dividing the testicular parenchyma into irregularly arranged lobules (Figure 2A). The septa finally met in a paraxial mediastinal strand and were formed of connective tissue, blood and lymph vessels.

The mediastinum was located paraxially toward the epididymal border and extended about two- thirds of the testicular length, it was thick at the head extremity, and contained a well-developed network of rete testis tubules (Figures 3A). Caudal wards, the mediastinal strand faded out gradually and showed few long, widely separated rete tubules (Figure 3B). At the head extremity, the mediastinum testis had a wide 


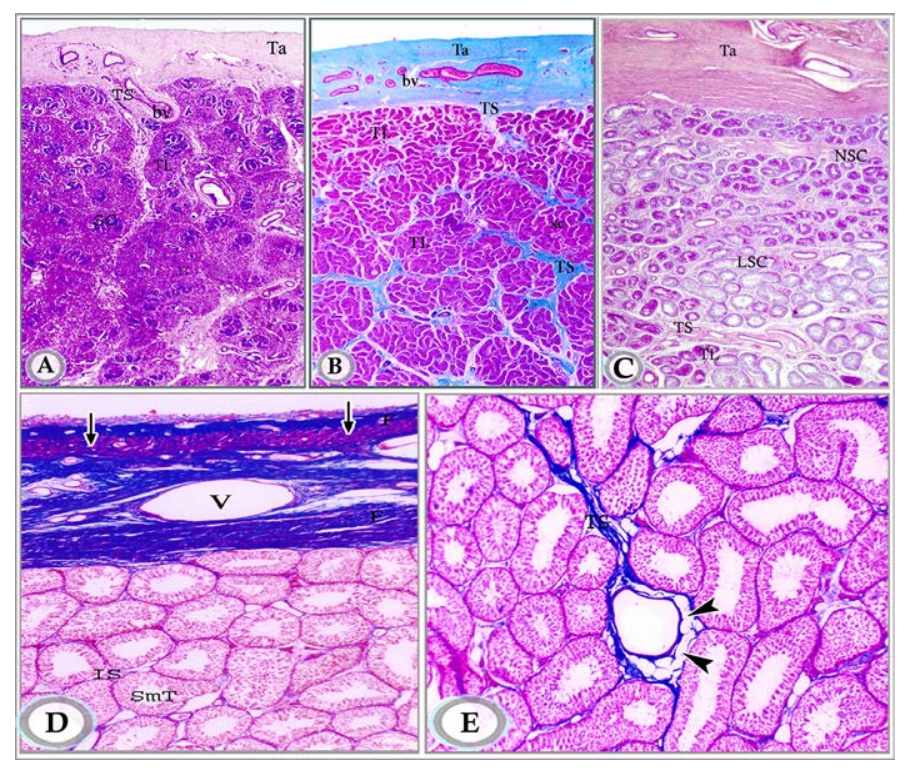

Figures 2A. Paraffin sections of testis of newly born donkey showing the tunica albuginea testicular septa and testicular lobules (Haematoxylin and Eosin, X25).

Figure 2B: Paraffin sections in testis of suckling donkey (2 months old) showing that the septa more branching leading to increase in the number of testicular lobules and showed variations in thickness along their course; they were thick in areas hosting testicular vessels and rete testis tubules. (Crossmon's trichrome, X25).

Note: tunica albuginea (Ta), testicular septum (Ts), seminiferous cords (SC), interstitial tissue (IT) and blood vessels (bv), testicular lobules (TL).

Figure 2C. Paraffin sections in testis of in premature donkey testis (1.5 year) showing large number of lobules of seminiferous cords (TL). The seminiferous cords have increased both in length and convolutions. Testicular septum (TS), non-luminated seminiferous cords (NSC), luminated seminiferous cords (LSC) (HE, X25).

Figure 2D and E: Testis of mature donkey ( 3 years old) showing the general structure of the testis. The tunica albuginea is formed of 3 layers outer and inner fibrous (F) in addition to the middle vascular layers (V). The testicular parenchyma is composed of numerous highly tortuous seminiferous tubules (SmT) separated by narrow interstitial spaces (IS).

Note the presence of a layer of smooth muscle fibers (arrows) in the outer fibrous layer (F) of the tunica albuginea and fat cells in the testicular septa (arrowheads).

contact with the tunica albuginea forming a pathway of the rete testis tubules to the epididymal duct via the efferent ductules (Figures 3C and 3D).

The seminiferous cords were interposed by randomly scattered, long straight tubules (tubuli recti). They appeared mostly tortuous with very narrow luminae (Figures $4 \mathrm{~A}$ and $4 \mathrm{~B}$ ). Branched tubules were seen in some areas and in most cases; a sharp cut contact was seen between these tubules and the seminiferous cords (Figures 4C and 4D). The wall of these tubules was formed of radially arranged columnar cells with deeply stained elongated oval nuclei that contained one or two small nucleoli and moderately stained cytoplasm (Figures 4A and 4B). The basement membrane appeared corrugated and showed PAS-positive reaction (Figures 11A).

\section{Suckling animals}

The tunica albuginea was consisted of inner and outer fibrous layers (mostly collagen fibers) separated by a middle vascular layer. The testicular septa showed more branching leading to increasing in the number of testicular lobules (Figures 2B). The septa showed variations in thickness along their course; they were thick in areas hosting testicular vessels and rete testis tubules.

The deeper septa communicated freely with the mediastinum testis. Such mediastinum maintained its shape; it was thick at the head

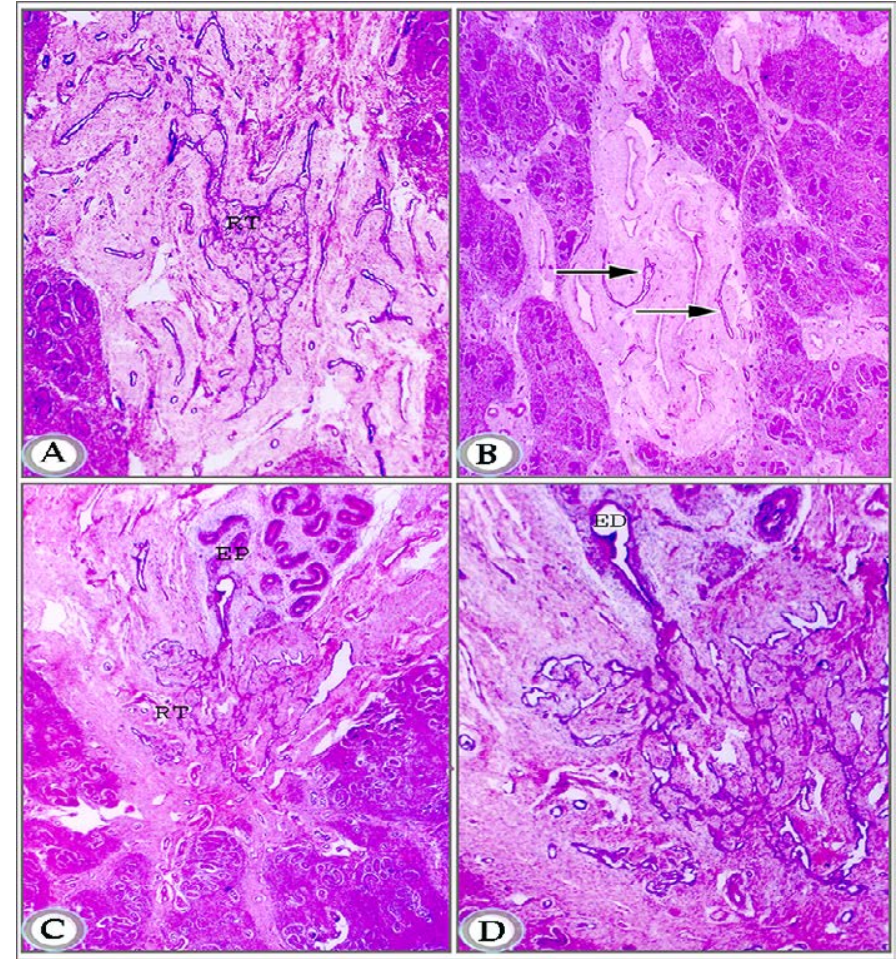

Figure 3A. Paraffin section in testis of a newly born donkey at the head extremity showing well- developed rete testis tubules (RT) within the mediastinum testis. (Haematoxylin and Eosin, X 50).

Figure 3B. Paraffin section in testis of newly born donkey midway between head and tail extremities showing few separately distributed rete testes tubules (arrows) within the mediastinum testis. (Haematoxylin and Eosin, X 25).

Figure 3C and D. Paraffin sections in testis of newly born donkey showing rete testis (RT), efferent ductules (ED) head of epididymis (EP). (Haematoxylin and Eosin, 6a: X 25,6b: X 50).

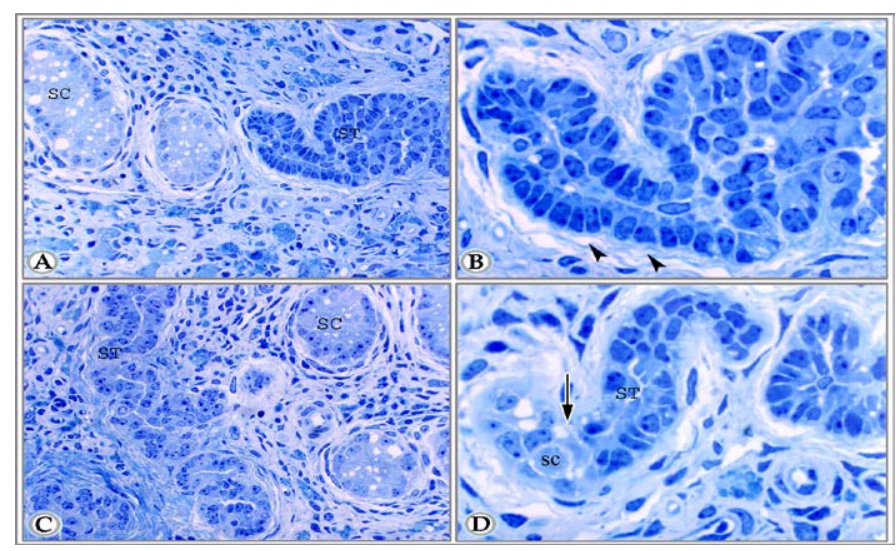

Figure 4A. Semithin section in testis of newly born donkey showing long tortuous tubul recti or straight tubule (ST) about to join a seminiferous cord (SC). (Toluidine blue, X 400). Figure 4B. A higher magnification of the latter figure (tubuli recti,ST). The lining cells are radially arranged on a corrugated basal lamina. The peritubular tissue consists of fine fibers of collagen (arrowheads). Notice the absence of peritubular cells in comparison to the seminiferous cords. (Toluidine blue, X 1000).

Figure 4C and D. Semithin section in testis of newly born donkey showing one of the straight testicular tubules (ST) branched in different directions beside seminiferous cords (SC). (Toluidine blue, X400).

extremity and became thin towards the tail extremity of the testis, where it contained few, and widely separated long rete tubules in addition to some testicular vessels (Figures 5A and 5B). 
The testicular duct system consisted of intralobular, interlobular and mediastinal segments, which finally connected with the epididymal duct through the efferent ductules (Figure 5 and Figure 6).

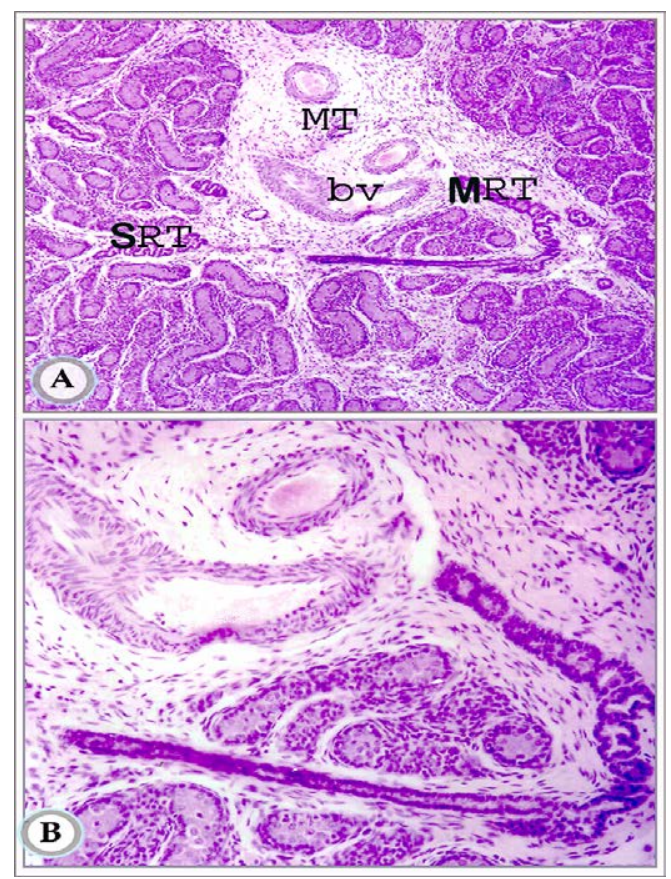

Figures 5A and B. Paraffin sections in testis of suckling donkey (2months old) showing the mediastinum testis (MT) mid-way between head and tail extremities. It contains blood vessels (bv) and some rete testis tubules. Notice the connection between the septal (SRT) and mediastinal (MRT) segments of the rete testis tubules. (Hematoxylin and Eosin, a: X63 and b: X160).

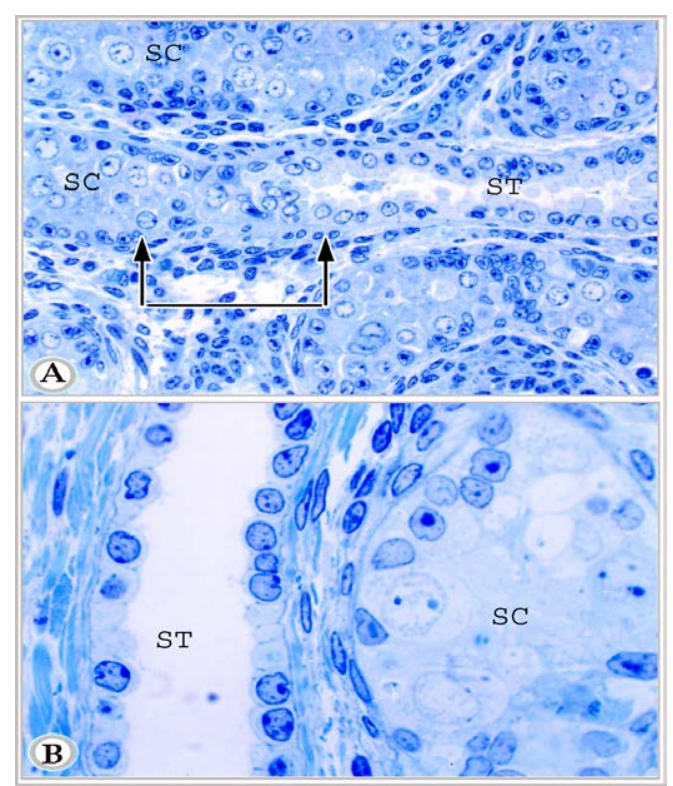

Figure 6A. Semithin section in the testis of suckling donkey (2 months old) showing seminiferous cords (SC), straight testicular tubule (ST). The delineated area represents the connection between seminiferous cord and straight testicular tubule. This area shows a constricted transitional zone. In this zone the supporting cells are crowded, some cells loss their contact with the basement membrane, others are degenerated. Notice the numerous crowded peritubular cells in this area (Toluidine blue, X 400).

Figure 6B. Semithin section in the testis of suckling animals ( 9 months old) showing seminiferous cord (SC), straight testicular tubule (ST). Notice that the lumen of straight testicular tubule is wide as compared with the latter figure. (Toluidine blue, X 1000)
The intralobular segment (the straight testicular tubules) appeared in either cross or longitudinal sections (Figure 6 and Figure 7). The latter form of these tubules was commonly seen communicating with the seminiferous cords (Figures 6A). The area of connection demonstrated a constricted transitional zone. In this zone, the supporting cells were crowded and irregularly arranged. Some cells had lost their contact with the basement membrane, sloughed and appeared centrally located. Signs of degeneration were demonstrated in some supporting and germ cells in this zone. Around this area, there were a large number of crowded, irregularly distributed peritubular fusiform cells with large or small deeply stained flattened or oval nuclei.

The wall of the straight testicular tubules consisted of a single layer of cuboidal to low columnar cells resting on a distinct basement membrane (Figures 6A and 6B). These cells had large oval nuclei with one or two nucleoli and distinct nuclear membrane. The nuclei appeared more deeply stained than those of the supporting cells of the cords. The lumen of these tubules was irregular and sometimes contained sloughed disintegrating cells. This lumen apparently increased in diameter with advancement of age (compare between (Figures 6A and 6B). The peritubular tissue around the straight tubules consisted mainly of a thick layer of collagen fibers.

The interlobular segment (septal rete testis tubules) exhibited a straight or tortuous course; some of them were connected with the mediastinal rete testis (Figures $5 \mathrm{~A}$ and $5 \mathrm{~B}$ ). The basement membrane appeared showed a PAS-positive reaction and wide lumen than previous age (Figure 11B).

\section{Premature animals}

The thickness of the tunica albuginea also increased in comparison with the previous age (Figure 2C).

The testicular excurrent duct system was represented, similarly as

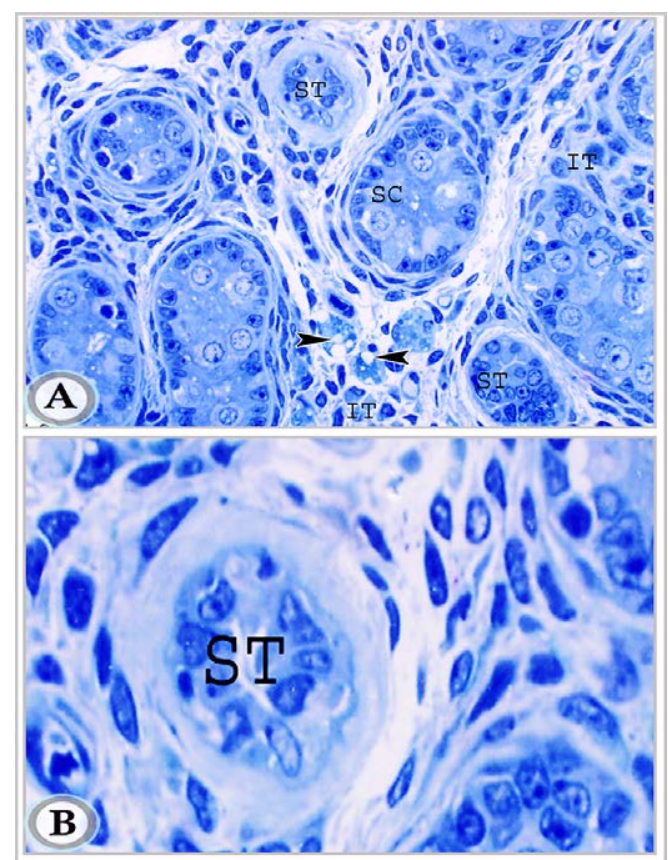

Figures 7A. Semithin section of testis in suckling donkey (2 months old) showing seminiferous cords (SC), two cross sections in intralobular straight testicular tubules (ST) and interstitial tissue (IT), Leydig cells (Arrowheads). (Toluidine blue, X 400).

Figures 7B. semithin section of testis in suckling donkey ( 2 months old) showing higher magnification of intralobular straight testicular tubules (ST). (Toluidine blue, X 1000). 
the previous age, by numerous tubules that were demonstrated amidst the seminiferous tubules (Figures $8 \mathrm{~A}$ and $8 \mathrm{~B}$ ), in the septa as well in addition to the mediastinal rete testis tubules (Figures $8 \mathrm{C}$ and $8 \mathrm{D}$ ). The basement membrane of these tubules showed strong PAS-positive reaction than previous age, In addition to wider lumen and secretory product present within the lumen (Figure 11C).

As described in the suckling animals, the connection between the seminiferous tubules and the straight testicular tubules was characterized by peculiar structural appearance that attained in this stage more modification and development. This connection included two regions: a terminal segment of the seminiferous tubules and a dilated initial part of the straight testicular tubule (tubuli recti). The terminal segment of the seminiferous tubules was slightly narrower. Most of the germ cells had lost their contact with the basement membrane; some of them underwent degeneration, while the supporting cells arranged themselves radially on the basement membrane. The dilated initial part of the straight tubule was lined by flat cells and contained numerous sloughed cells in its lumen. The rest of the straight tubule was lined with a single layer of cuboidal cells with rounded or oval nuclei (Figure 8A).

\section{Mature animals}

The tunica albuginea maintained its previous structure of outer and inner fibrous layers in addition to the middle vascular one. A striking feature of the tunica albuginea, in mature animals, was the presence of a prominent layer of smooth muscle fibers in its outer fibrous layer (Figure 2D). The irregular lobular arrangement described in the previous stages remained a characteristic feature. (Figure 2E).

The excurrent duct system of mature testis maintained the peculiar structure of the previous stage, which represented by intralobular, interlobular tubules and mediastinal rete testis tubules, which connected with the efferent ductules. The basement membrane of these tubules showed strong PAS-positive reaction than pervious age, In addition to wider lumen and secretory product present within the lumen (Figure 11D).

In addition, other tubules (tunical rete tubules) were also demonstrated running in some areas in the inner fibrous layer of the tunica albugenia and were connected to the interlobular tubules

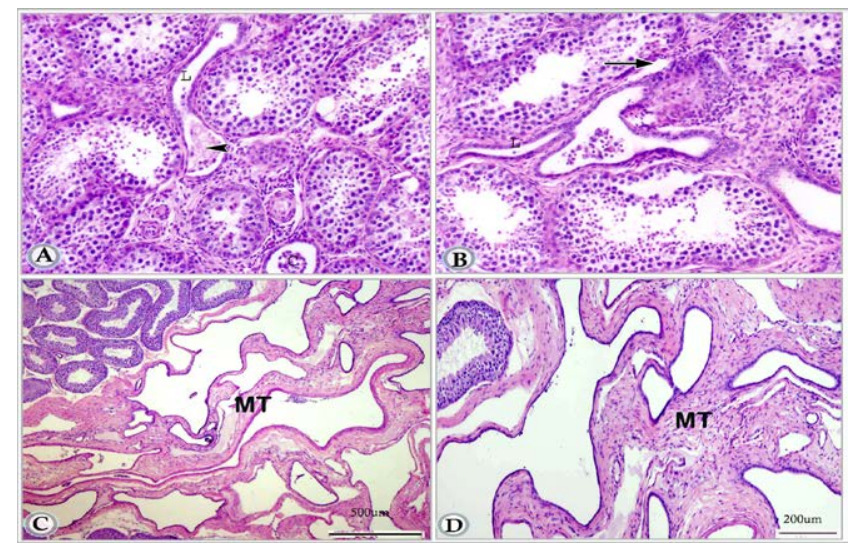

Figures 8. A and B. Paraffin sections in premature donkey testis (1.5 year) showing straight testicular tubules in cross (C) and longitudinal (L) sections. These tubules are lined by single layer of low cuboidal cells. Note the connection between one of these tubules and the terminal segment of the seminiferous tubule (arrow). The initial part of the striaght tubule is dilated and contains collections of sloughed cells (arrow head). (Haematoxylin and Eosin, a: X 63, b: X 160)

Figures $8 \mathrm{C}$ and D. Paraffin sections in premature donkey testis (1.5 year) showing the mediastinum testis (MR).
(Figures 10A and 10B). The tubules had a wide irregular lumen and lined with low cuboidal cells with deeply stained oval nuclei. Secretory products (spermatozoa) were observed within the rete tubules (Figure 10B).

The terminal segment of the seminiferous tubule attained its final mature picture; it was composed of three regions with different cellular composition; the first region showed incomplete spermatogenesis, many germ cells showed signs of degenerative changes, but a distinct lumen was visible in this part. The second part demonstrated radially arranged vacuolated supporting cells; germ cells were rarely seen in this region. In the third region, the supporting cell apices projected in the cup- shaped initial segment of the straight testicular tubules forming plug- shaped protrusion (Figures 9B and 9C).

\section{Discussion}

Previous studies have demonstrated that difference in time of descending of testes in different species. The current study revealed that the testis of the donkey was completely descended into the scrotum in all neonatal animals (first week of life) except one animal whose right testis was seen at the scrotal neck. From these findings, it can be postulated that the testis of the donkey descends in the scrotum around birth. A Similar statement was recorded by Bergin, et al. who gave a range from about 30 days before birth to 10 days after birth to the testicular descent in the horse [17]. The testis of the pig was already in the scrotum at birth [18]. In the camel, the testis of the full-term fetus was seen in the perineal region, near the scrotum [19]. Contrarily, a much earlier descent (around the beginning of the $6^{\text {th }}$ gestational month) was stated in bovines and buffalo [20,21]. However, much late descent (35-40 postnatal days) was recorded in the dog [22,23]. The mechanism of testicular descent is not yet completely understood. Various authors have given different explanations of the factors involved in this process. Changes in the gubernaculum testis, dependence on androgen

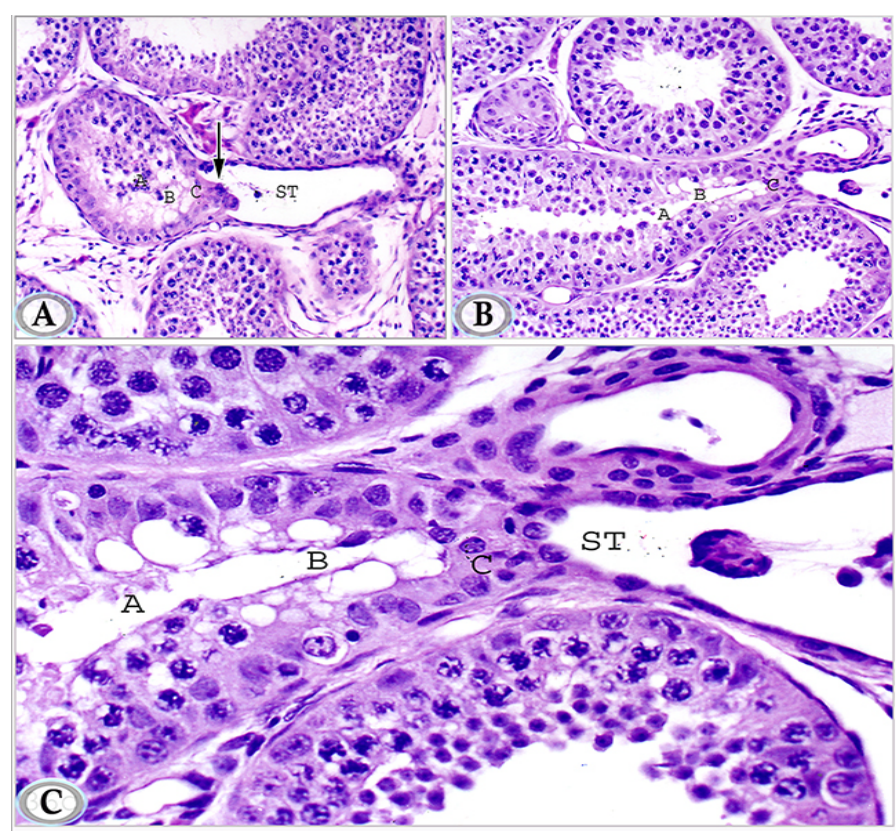

Figures 9. A, B and C. Paraffin sections in the testis of mature donkey showing the terminal segment of the seminiferous tubules. The latter segment is formed of three regions: the first region (A) shows incomplete spermatogenesis, the second region (B) is lined by radially arranged vacuolated supporting cells, the third region $(\mathrm{C})$, the supporting cells apices protrudes in the form of terminal plug (arrow) in to the cup- shaped initial segment of the straight testicular tubule (ST). Haematoxylin and Eosin, a, b: X 200 and c: X 400) 


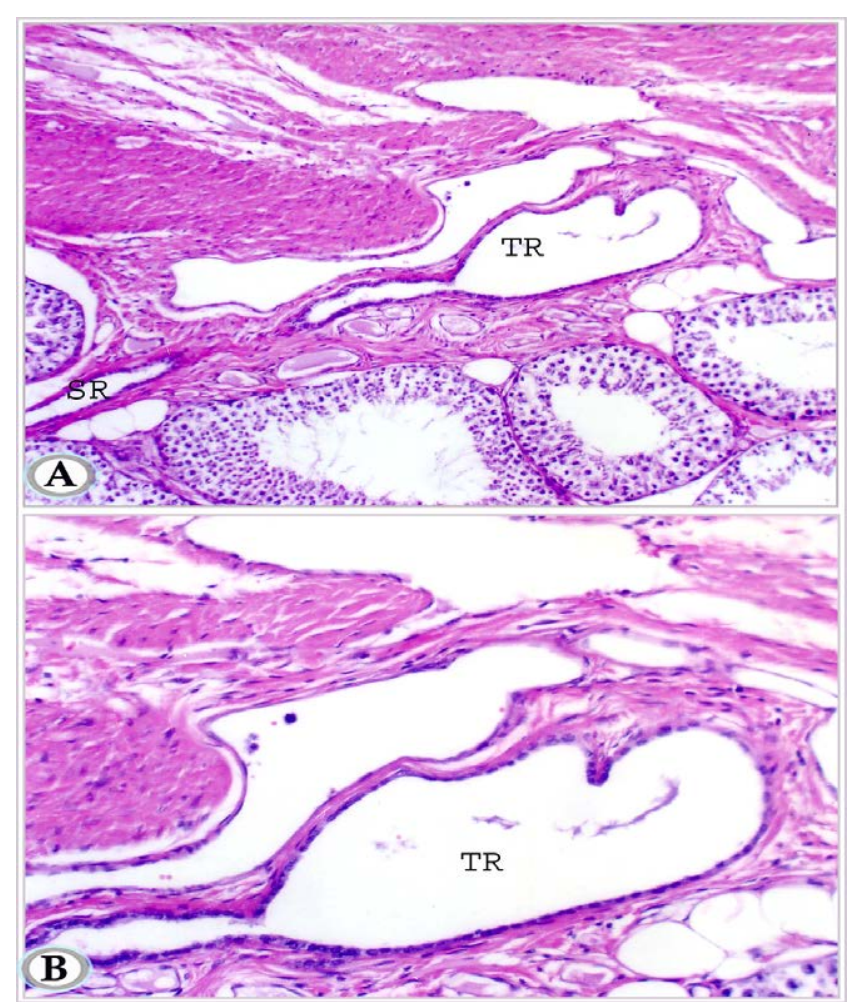

Figures 10. A and B. Testis of mature donkey (3 years old) showing tunical rete testis tubules (TR) with dilated lumen; lined by single layer of low cuboidal cells. Note these tunical rete testis tubules are continuous with septal rete tubules (SR). (Hematoxylin and Eosin, a: X 100 and b: X 200)

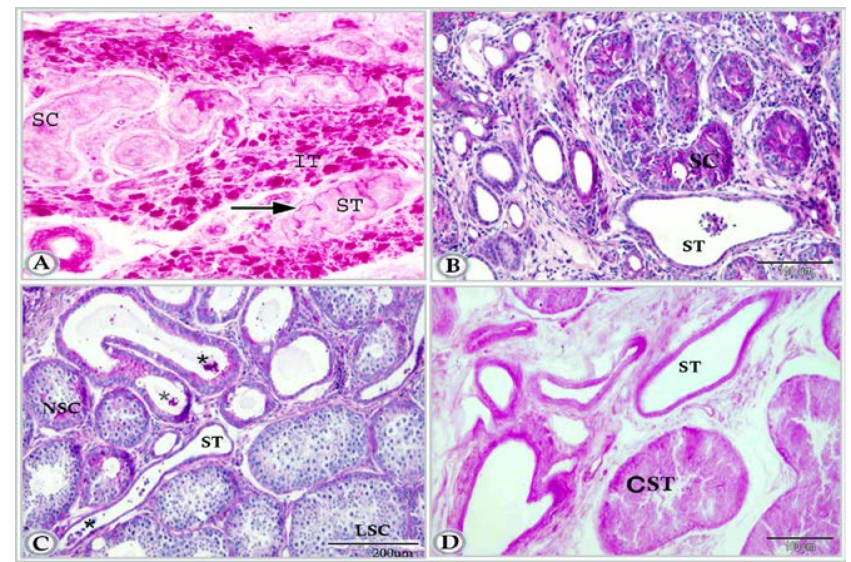

Figure 11A. Paraffin section in testis of newly born donkey showing seminiferous cord (SC), interstitial tissue (IT) and straight testicular tubule (ST). Notice the positively reacted basal laminae of the straight tubule (arrow) and the strong PAS positive reaction in the cells of interstitial tissue. (Periodic acid Schiff reagent, X200).

Figure 11B. Paraffin section in testis of suckling donkey (6 months old) showing the positively reacted straight tubule (ST) (Periodic acid Schiff reagent and Hematoxylin).

Figure 11C. in premature donkey testis (1.5 year) showing the positively reacted straight tubule (ST). Note, Luminated cords (LSC) and non-luminated cords (NSC), secretion within the lumen of duct $(*)$ (Periodic acid Schiff reagent and Heamtoxlyin).

Figure 11D. Testis of mature donkey ( 3 years old) showing strong reaction in the straight tubules. Note, the cross section of seminiferous tubules (CST). (Periodic acid Schiff reagent).

and gonadotrophins and the role of Müllerian inhibitor factor have been suggested to be involved in this process [24-28]. Moreover, an unknown testicular factor has been also assumed to induce testicular descent completely descended into the scrotum around birth in this investigation [29].
The developing testis of the donkey was covered by a tunica albuginea consisting of an outer and inner fibrous layer in addition to middle vascular one. In mature donkeys, bundles of smooth muscle cells were demonstrated in the outer fibrous layer of the tunica albuginea. In the same concern, Dellmann and Wrobel reported that smooth muscle cells are occasionally seen in the tunica albuginea of stallion [2]. These smooth muscle cells may give the tunica albuginea a contractile function that may aid in sperm transport [30-32]. Contrarily, although Chacon-Arellano and Woolley ascertained the presence of smooth muscle fibers in the tunica albuginea of the horse, pig, and sheep, they denied any primary role of these muscles in sperm transport [33]. They added that these capsular muscles are continuous with the smooth muscles associated with the vasculature of the spermatic cord in the horse. They suggested that it may, perhaps, has a role in assisting the blood or lymphatic drainage from the cord, or it may possibly represent a primitive auxiliary suspensory device.

The present study emphasized an irregular arrangement of the testicular lobules of the donkey during various stages of the postnatal life. The same result was recorded by Moustafa et al. [34]. Such arrangement does not allow some lobules to have direct contact with the mediastinum testis; hence their duct system may follow septal or tunical ways to gain the mediastinum or efferent ductules, respectively.

Unlike, the case in other domestic animals such as ruminants, pigs and dogs where the mediastinum occupied a central position, the mediastinum testis of the donkey in the current work was located paraxially toward the epididymal border [4]. It extended two-thirds of the testicular length. However, the previous investigations are contradictory concerning the existence, position, and extension of the equine mediastinum and rete testis. Some authors Flemming, Montane, Bourdelle, Montane, et al. described a conspicuous mediastinum which contained the rete testis and extended at least two thirds the length of the testis [35-37]. Others (Roberts; Banks; Getty) reported that a distinct mediastinum or rete testis (or both) were lacking in the equine testis [38-40]. Bastrop concluded that in most stallions the mediastinum testis ran from the dorso-cranial pole in an arc into the third quarter of the testis [41]. Nickel, et al. inferred that the equine testis contained a mediastinum, which was confined to the cranial end of the testis where the efferent ducts penetrated the tunica albuginea [42]. In our opinion, this controversy could be attributed to the presence of the main bulk of the rete testis in the part of the mediastinum testis, which located at the head extremity.

The present study revealed also that the terminal segment of the seminiferous tubules in adult donkeys was composed of three regions with different cellular composition. These results support the findings of Wrobel, et al. who mentioned that the terminal segment of the seminiferous tubule is tripartite consisting of transitional region, intermediate portion, and terminal plug [43]. The sustentacular cell apices in the terminal plug project into the cup-shaped initial portion of the straight testicular tubules. All spermatozoa have to pass through the narrow intercellular slits between adjacent modified sustentacular cells on their way to the straight tubule. The terminal segment may further function as a valve that prevents the reflux of rete testis fluid into the seminiferous tubules [4].

The nomenclature and origin of the excurrent duct system of the testis are a matter of controversy. In the present study, the testicular duct system of donkey included intralobular, interlobular mediastinal and tunical segments in addition to the efferent ductules. The current findings simulate those of Roosen-Runge and Holstein who mentioned that the definition of the rete testis is based on the characteristic lining 
epithelium [44]. From seminiferous tubules to efferent ductules, this epithelium is essentially the same in general cellular composition and ultrastructural features; however, the passage differs in size and configuration from region to another. Embryologically, Wrobel ascertained that the blastema of bovine rete testis (ovarii) and of the gonad proper are two tissue complexes that enter independent differentiation pathways and acquire particular histochemical and ultrastructural features [45].

The intralobular segment of the excurrent duct system is commonly known as the straight portion of the seminiferous tubules. However, Wrobel, in a developmental ultrastructural and immuno-histochemical study, emphasized that the straight seminiferous tubules appeared for the first time as a central zone of thin testicular cords of the 40 to 45 days old bovine embryos [46]. He ascertained that these thin cords were transient, but they maintain a system of continuous basal lamina that brings the peripheral rete extensions in direct contact with the central ends of the growing seminiferous tubules. According to the same author, the strongly proliferating rete cells advance along the continuous basal lamina into the confines of the seminiferous tubules with a concomitant separation of the pre-Sertoli cells from their basal lamina in these areas. All pre-Sertoli cells and spermatogonia within the elongating straight testicular tubules finally undergo apoptosis. By the ongoing proliferation of the rete cells within the straight testicular tubules, the latter elongates continuously, and the border between the rete system and the seminiferous tubules is slowly shifted towards the testicular periphery.

Septal segments of rete tubules as those recorded in goat, bovines and cat were demonstrated in the present study $[7,8,10]$. These septal segments connect the terminal parts of the seminiferous tubules with the mediastinal rete [7]. In our opinion, the septal rete tubules represent a pathway for the drainage of the testicular lobules that have no direct contact with the mediastinum testis.

Tunical rete tubules were demonstrated in the current study especially near the head extremity of the testis. Similar findings have been also recorded in cat, where tunical rete tubules appeared communicating with the extra-testicular rete testis [10].

\section{Conclusion}

The mediastinum testis of donkey was located paraxially, toward the epididymal border and extended about two-thirds of the testicular length; it is thick at the head extremity and gradually faded out caudal wards. The duct system of the donkey testis included an intralobular, interlobular, mediastinal and tunical segments in addition to the efferent ductules. From the seminiferous tubules to the efferent ductules, the lining epithelium was essentially the same in cellular composition; however, these passages differed in size and configuration from region to another.

\section{References}

1. Siuand MKY, Cheng CY (2004) Dynamic cross-talk between cells and the extracellular matrix in the testis. BioEssays: 978-992. [Crossref]

2. Dellmann HD, Wrobel KH (1976) Male reproductive system. Text Book of Veterinary Histology. Dellmann HD and Brown EM (eds). Lea and Febiger Philadelphia, USA.

3. Banks WJ (1993) Applied veterinary histology $3^{\text {rd }}($ edn). Mosby Year Book, St. Louis, USA.

4. Wrobel KH, Dellmann HD (1993) Male reproductive system. In Text Book of Veterinary Histology Edited by Dellmann HD $4^{\text {th }}(\mathrm{edn})$. Lea and Febiger Philadelphia, USA.

5. Wrobel KH, Sinowatz F, Mademann R (1982) The fine structure of the terminal segment of the bovine seminiferous tubule. Cell Tissue Res 225: 29-44.[Crossref]

6. Amann RP, Johnson L, Pickett BW (1977) Connection between the seminiferous tubules and the efferent ducts in the stallion. Am J Vet Res 38: 1571-1579.[Crossref]

7. Goyal HO, Williams CS (1987) The rete testis of the goat, a morphological study. Acta Anat (Basel) 130: 151-157.[Crossref]

8. Hees H, Wrobel KH, Kohler T, Leiser R, Rothbächer I, et al. (1987) Spatial topography of the excurrent duct system in the bovine testis. Cell Tissue Res 248: 143-151. [Crossref]

9. Ahmed A, Sinowatz F (2005) Morphological, Glycohistochemical, and Immunohistochemical Studies on the Embryonic and Adult Bovine Testis. PhD thesis Ludwig Maximilians University Munich.

10. Viotto MJ, Orsi AM, Mello Dias S, Newmann HK (1991) [Structure of the rete testis of the cat (Felis domestica, L)]. Anat Anz 172: 341-349.[Crossref]

11. Wrobel KH, Moustafa MN (2000) On the innervation of the donkey testis. Ann Anat 182: 13-22.[Crossref]

12. Harris HF (1898) A new method of ripening hematoxylin. In Mikroskopische Technik Romeis (eds) Oldenburg, München.

13. Crossmons G (1937) A modification of Mallory's connective tissue stain with discussion of the Principle involved. Anat Rec 69: 33-38.

14. Mc Manus JF (1948) Histological and histochemical uses of periodic acid. Stain Technol 23: 99-108.[Crossref]

15. Karnovsky MJ (1965) A Formaldehyde-Glutaraldehyde Fixative of High Osmolarity for use Electron Microscopy. Cell Biol:27137A.

16. Bancroft JD, Layton C, Suvarna, SK (2013) Bancroft's Theory and Practice of Histological Techniques. $7^{\text {th }}(\mathrm{edn})$. Elsevier Health Sciences Churchill Livingstone.

17. Bergin WC, Gier HT, Marion GB, Coffman JR (1970) A developmental concept of equine cryptorchism. Biol Reprod 3: 82-92.[Crossref]

18. Wensing CJ (1973) Testicular descent in some domestic mammals. 3. Search for the factors that regulate the gubernacular reaction. Proc K Ned Akad Wet C 76: 196-202. [Crossref]

19. Ahmed AM (1994) Histogenesis of the testis in one humped camel. PhD Thesis Fac Vet Med Tanta University.

20. Evans HE, Sack WO (1973) Prenatal development of domestic and laboratory mammals: Growth curves, external features and selected references. Zentralbl Veterinarmed C2: 11-45. [Crossref]

21. Abdel-Raouf M, EL-Naggar MA, EL-Bab MR (1974) The development of the feta testis in the buffalo. Z Anat Entwicklungsgesch 144: 227-236.[Crossref]

22. Evans HE (1993) The reproductive organs: In Miller's Anatomy of the dog. $3^{\text {rd }}(\mathrm{edn})$ WB Saunders Company, Philadelphia, USA: 511.

23. Zayed AE and Moustafa MNK (1996) A histomorphological study on the testis of dog during postnatal life. Assiut Vet Med J 20: 31-46.

24. Backhouse KM (1964) The gubernaculum testis hunteri: testicular descent and maldescent. arris and gale lecture delivered at the royal college of surgeons of england on 27th october 1959. Ann R Coll Surg Engl 35: 15-33.[Crossref]

25. Gier HT, Marion GB (1969) Development of mammalian testis and genital ducts. Biol Reprod 1: 1-23.[Crossref]

26. Wensing CJG (1986) Testicular descent in the rat and a comparison of this process in the rat with the pig. Anat Rec214: 154-160.

27. Elder JS, Issacs JT, Walsh PC (1982) Androgen sensitivity of gubernaculum testis: Evidence of hormonal mechanical interactions in testicular descent. J Urol127: 170176. [Crossref]

28. Hutson JM (1985) A biphasic model for the hormonal control of testicular descent Lancet 2: 419-421.[Crossref]

29. Fentener Van Vlissmgen JM (1988) Models of testicular descent in vivo and vitro. Thesis, Utrecht University.

30. Holstein AF (1967) Die glatte Muskulatur in der Tunica albuginea des Hodens und ihr Einfluss auf den Spermatozoentransport in den Nebenhoden. Verhandlungen der anatomischen Gesellschaft 62: 103-108.

31. Davis JR, Langford GA (1970) Pharmacological studies on the testicular capsule in relation to sperm transport. In the human testis (eds) Rosenberg E and Paulsen CA). Adv Exp Med Biol 10: 495-514. 
32. Lesson TS, Cookson FB (1974) The mammalian testicular capsule and its muscle elements. Journal of Morphology 144: 237-254.

33. Chacon-Arellano JT, Woolley DM (1980) Smooth muscle cells in the testicular capsule of the horse, pig and sheep. J Anat 131: 263-273.[Crossref]

34. Moustafa MNK, Sayed R, Zayed AE, Abd EL-Hafeez (2015) Morphological and Morphometric Study of the Development of Seminiferousof Donkey (Equus asinus) from Birth to Maturity. J Cytol Histol 6: 370 .

35. Flemming G (1906) The comparative anatomy of the domesticated animals. $2^{\text {nd }}(\mathrm{edn}) \mathrm{D}$. Appleton Company, New York, USA: 963-964.

36. MontaneL and Bourdelle E (1913) Anatomie Regionale des Animaux Domestiques. I Cheval JB Baillire rt Fils Paris France: 821.

37. Montane L, Bourdelle E, Bressou C (1949) Anatomie Regionale des Animaux Domestiques I Equides $9^{\text {th }}(\mathrm{edn})$. JB Baillire ET Fils, Paris, France: 721-724.

38. Roberts SJ (1971) Veterinary obstetrics and genital diseases. $2^{\text {nd }}($ edn). SJ Roberts, Ithaca, NY: 605.

39. Banks WJ (1974) Histology and Comparative Organology. Williams and Wilkins Company, Baltimore, USA: 232.
40. Getty R (1975) Urogential system. In Sisson and Grossman's The Anatomy of the Domestic Animals. $5^{\text {th }}$ (edn). WB Saunders Company, Philadelphia, USA: 532.

41. Bastrop H (1958) Form Gewicht Masse Mediastinum testis und die oberflächliche Gefässzeichung des Hodens von Schwein und Pferd.Veterinary Medicine Dissertation Humboldt Universität Berlin Germany.

42. Nickel R, Schummer A, Seiferle E, Sack WO (1973) The viscera of the domestic mammals. Springer-verlag New York, USA: 305-340.

43. Wrobel KH, Schilling E, Zwack M (1986) Postnatal development of the connexion between tubulus seminiferous and tubulus rectus in the bovine testis. Cell Tissue Res 246: 387-400.[Crossref]

44. Roosen-Runge EC, Holstein AF (1978) The human rete testis. Cell Tissue Res 189 409-433.[Crossref]

45. Wrobel KH (2000) Morphogenesis of the bovine rete testis: the intratesticular rete and its connection to the seminiferous tubules. Anat Embryol (Berl)202: 475-490.[Crossref]

46. Wrobel KH (2000) Prespermatogenesis and spermatogenesis in the bovine testis. Anat Embryol 202: 209-222.[Crossref]

Copyright: $@ 2017$ Abd-Elhafeez HH. This is an open-access article distributed under the terms of the Creative Commons Attribution License, which permits unrestricted use, distribution, and reproduction in any medium, provided the original author and source are credited. 